ТЕОРІЯ І МЕТОДИКА ПІДГОТОВКИ

СПОРТСМЕНІВ

\title{
ORGANIZATION AND CONTROL OF SPECIAL STRENGTH TRAINING OF QUALIFIED FOOTBALL PLAYERS
}

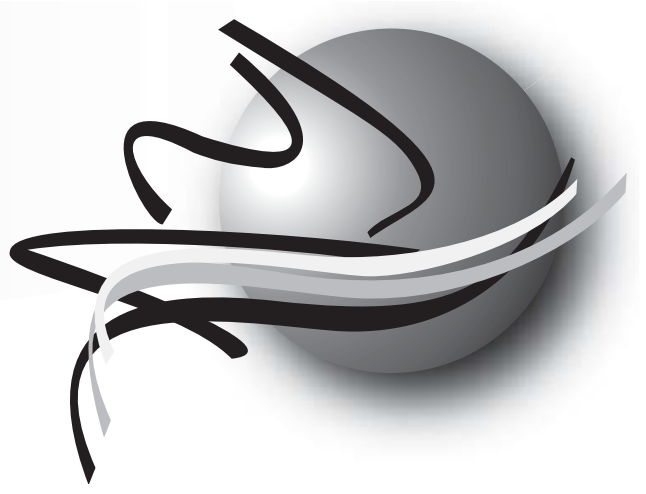

\author{
Lashkevich Sergey ${ }^{l}$, Vrublevskiy Evgeniy ${ }^{1,2}$, Kozhedub Marina ${ }^{1}$, \\ Medvedev Pavel ${ }^{1}$
}

${ }^{1}$ Educational Establishment «Francisk Skorina Gomel State University»

${ }^{2}$ University of Zielona Góra

\section{DOI: 10.32540/2071-1476-2021-3-064}

\section{Annotation}

Introduction. The relevance of the study is related to the importance of evaluating the effectiveness of various training methods aimed at developing the strength abilities of football players, as well as the need to determine the optimal options for combining them with other training influences in the process of training players at various structural units of the annual cycle. The purpose of the study is to develop and scientifically substantiate the methodology for assessing and monitoring the special strength training of qualified football players. Research methods. To assess the strength indicators, as well as to track the dynamics of their development, the use of the method of computer strainkinamography is the most effective and efficient, which allows not only to detail and accurately determine the dynamometric characteristics of the subjects, but also to quickly process and analyze the results in sufficient detail.

The results of the study. The data obtained showed that with an increase in the power component, an increase in speed abilities follows, which has a positive effect on the playing activity of football players. The individualization of special strength training of qualified football players, carried out by selecting the optimal weight for each player, as well as a set of speed and strength exercises, had a positive effect on the indicators of the dynamic characteristics of the players. The variation in different modes (isometric, dynamic, and statodynamic) of individually directed training actions allowed for a more complete effect on the muscle fibers of the players, which contributed to the qualitative manifestation of the players' conditions in training and competitive activities. Conclusions. The rational organization of special strength training of football players and the development of objective control over the level and dynamics of their strength characteristics should be considered as a potential reserve that contributes to the qualitative improvement of the training process of qualified football players of various playing roles.

Keywords: Strength; technique; game; exercises; training process, speed, players, footbal.

\section{Анотація}

Вступ. Актуальність дослідження пов'язана зі значущістю оцінки ефективності різних методів тренування, спрямованих на розвиток силових здібностей футболістів, а так само необхідністю визначити оптимальні варіанти їх поєднання з іншими тренувальними впливами в процесі підготовки гравців на різних структурних одиницях річного циклу. Мета дослідження - розробити та науково обгрунтувати методику оцінки та контролю спеціальної силової підготовленості кваліфікованих футболістів. Методи дослідження. Для оцінки силових показників, а також відстеження динаміки їх розвитку найбільш ефективне і результативне використання методу комп'ютерної тензодинамографії, що дозволяє не тільки деталізувати і точно визначати динамометричні характеристики випробовуваних, але швидко, а також досить детально обробляти і аналізувати отримані результати.

Результати дослідження. Отримані дані показали, що зі збільшенням силового компонента йде підви- 
щення швидкісних здібностей, що позитивно позначається на ігровій діяльності футболістів. Індивідуалізація спеціальної силової підготовки кваліфікованих футболістів, здійснювана шляхом підбору оптимальної ваги обтяження для кожного гравця, а також комплексу швидкісно-силових вправ позитивно позначилися на показниках динамічних характеристик гравців. Варіація в різних режимах (ізометричному, динамічному, статодинамічному) індивідуально спрямованих тренуючих впливів дозволила більш повноцінно впливати на м'язові волокна гравців, що сприяло якісному прояву кондицій гравців в тренувальній і змагальної діяльності. Висновок. Раціональну організацію спеціальної силової підготовки футболістів і розробку об'єктивного контролю за рівнем і динамікою їх силових характеристик слід розглядати як потенційний резерв, що сприяє якісному вдосконаленню тренувального процесу кваліфікованих футболістів різного ігрового амплуа.

Ключові слова: Сила, техніка, гра, вправи, тренувальний процес, швидкість, гравці, футбол.

\section{Аннотация}

Введение. Актуальность исследования связана со значимостью оценки эффективности различных методов тренировки, направленных на развитие силовых способностей футболистов, а так же необходимостью определить оптимальные варианты их сочетания с другими тренирующими воздействиями в процессе подготовки игроков на различных структурных единицах годичного цикла. Цель исследования - разработать и научно обосновать методику оценки и контроля специальной силовой подготовленности квалифицированных футболистов. Методы исследования. Для оценки силовых показателей, а также отслеживания динамики их развития наиболее эффективно и результативно использование метода компьютерной тензодинамографии, позволяющего не только детализировать и точно определять динамометрические характеристики испытуемых, но быстро, а также достаточно подробно обрабатывать и анализировать полученные результаты.

Результаты исследования. Полученные данные показали, что с увеличением силового компонента следует повышение скоростных способностей, что положительно сказывается на игровой деятельности футболистов. Индивидуализация специальной силовой подготовки квалифицированных футболистов, осуществляемая путем подбора оптимального веса отягощения для каждого игрока, а также комплекса скоростно-силовых упражнений положительно сказалось на показателях динамических характеристик игроков. Вариация в различных режимах (изометрическом, динамическом, статодинамическом) индивидуально направленных тренирующих воздействий позволила более полноценно воздействовать на мышечные волокна игроков, что способствовало качественному проявлению кондиций игроков в тренировочной и соревновательной деятельности. Выводы. Рациональную организацию специальной силовой подготовки футболистов и разработку объективного контроля за уровнем и динамикой их силовых характеристик следует рассматривать как потенциальный резерв, способствующий качественному совершенствованию тренировочного процесса квалифицированных футболистов различного игрового амплуа.

Ключевые слова: Сила, техника, игра, упражнения, тренировочный процесс, быстрота, игроки, футбол.

Problem statement. Football is a sport that includes the manifestation of all physical qualities. At the same time, qualified players must have high indicators of the power component to realize themselves in competitive activity $[2,4,5,8,9$, 12, 22, 23]. However, the opinions of football coaches-practitioners are not always the same. Some believe that for the game implementation, a football player should take the time to develop this quality. Others - that athletes should not perform the load with an external load. In our opinion, players are required to perform strength exercises that, by strengthening the muscle fibers, will reduce the risk of injuries and increase the effectiveness of competitive activities. Thus, an increase in the power capabilities of a football player directly affects the speed of hitting the ball, since the speed of the latter's flight depends on the force applied to it $[14,15]$.

Analysis of scientific research and publications. It is important for football practice to evaluate the effectiveness of various training methods aimed at developing strength abilities, as well as the need to determine the optimal options for combining them with other training influences in the process of training players at various structural units of the annual cycle $[3,11,13,18,18$, $19,20,21,24,27]$. To date, there are a large number of tools, methods and methodological techniques that underlie the development of a certain type of strength, taking into account the specifics of this sport [ 1 , $6,7,10,16,17,18,19]$. At the same time, the measurement of power characteristics and the process of changing them over time cannot always be determined using pedagogical tests. To assess the strength indicators, as well as to track the dynamics of their development, it is most effective and efficient to use the method of computer tensodinamography, which allows not only

(C) Lashkevich S., Vrublevskiy E., 
to detail and accurately determine the dynamometric characteristics of the subjects, but also to quickly process and analyze the results in sufficient detail.

Methods and organization of the study. The testing took place on the basis of the foot-sick club "Lokomotiv" in Gomel, which plays in the second division of the Republic of Belarus. The study involved 20 players aged 18 to 34 years ( 8 defenders, 8 midfielders and 4 forwards). The research took place throughout the entire season, from January to November 2020. For an instrumental assessment of the strength and speed-strength capabilities of the muscles of football players, the method of computer tensodinamography was used, which made it possible to record the "strength-time" curve, as well as to observe the rate of increase in muscle strength $[1,25,26]$. The maximum force registered at the manifestation of the isometric tension of the muscle group without fixing the time was determined, the "explosive" muscle contraction in the isometric mode was estimated - the force gradient (the ratio of the maximum manifested muscle effort to the time of its achievement) and the values of strength indicators that athletes can develop in $0.1 \mathrm{~s}[1,24]$.
The obtained tensodynamograms of the strength characteristics of the muscle groups involved in leg extension in the knee and hip joints were recorded and processed.

The purpose of this study is to develop and scientifically substantiate a methodology for assessing the special strength training of qualified football players.

The training process was designed in such a way that anaerobic strength training was performed twice a week. On Wednesdays, strength training was carried out, and every Sunday, the focus was on toning the muscle fibers on the day after the friendly matches.

Research results and their discussion. Analysis of the results of dynamometry showed that the strength indicators of the players at the beginning of the experiment are approximately at the same level (Table 1). The values of the maximum isometric force and the maximum explosive force of the players are almost identical $(\mathrm{p}>0.05)$. There were no significant statistical differences between these groups in all power manifestations. It should be emphasized that a very significant indicator is the manifestation of force in 0.1 seconds. The latter is due to the fact that the running speed is determined by a number of parameters, the main of which is the repulsive force, which directly affects the length of the athlete's running step. Football players spend approximately $0.1-0.2 \mathrm{~s}$ when interacting with the foot support [15, 20]. Therefore, in our opinion, the determining factor in assessing the strength characteristics of football players should be the strength of the player shown during this period of time.

Based on the tasks which were set to increase the strength component of the players, a training plan was drawn up based on the method of unsaturated effort. The control group players performed anaerobic strength training once every two weeks. The football players of the experimental group performed similar training exercises twice a week. For each player of the experimental group, their optimal weight was selected in all exercises. The duration of the training session for the athletes of the control group was 150 minutes per month, for the players of the experimental group - 540 minutes per month.

Taking into account the above, the main means of developing force effects were selected, which included the following exercises:

1. Exercises with external weights, performed on the number

\section{Dynamometric indicators of qualified football players before the experiment}

\begin{tabular}{|l|c|c|c|c|}
\hline \multirow{2}{*}{\begin{tabular}{c}
\multirow{2}{*}{$\begin{array}{c}\text { Dynamometric } \\
\text { Indicators }\end{array}$} \\
\cline { 2 - 5 }
\end{tabular}} & $\begin{array}{c}\text { Control } \\
\mathrm{n}=10\end{array}$ & $\begin{array}{c}\text { Experimental } \\
\mathrm{n}=10\end{array}$ & Validity of differences \\
\hline \multicolumn{5}{|c|}{ Right leg } \\
\hline Maximum isometric force, $\mathrm{kg}$ & $206,9 \pm 8,3$ & $205,4 \pm 9,4$ & 0,12 & $\mathrm{p}$ \\
\hline Force gradient, $\mathrm{kg} / \mathrm{s}$ & $165,7 \pm 8,5$ & $171,4 \pm 6,2$ & 0,54 & $>0,05$ \\
\hline Force exerted in $0,1 \mathrm{~s}, \mathrm{~kg}$ & $111,9 \pm 7,0$ & $120,5 \pm 8,1$ & 0,80 & $>0,05$ \\
\hline \multicolumn{7}{|c|}{ Left leg } \\
\hline Maximum isometric force, $\mathrm{kg}$ & $196,5 \pm 7,6$ & $196,7 \pm 8,3$ & 0,02 & $>0,05$ \\
\hline Force gradient, $\mathrm{kg} / \mathrm{s}$ & $159,1 \pm 7,9$ & $152,1 \pm 8,1$ & 0,62 & $>0,05$ \\
\hline Force exerted in $0,1 \mathrm{~s}, \mathrm{~kg}$ & $110,4 \pm 4,6$ & $117,6 \pm 6,3$ & 0,91 & $>0,05$ \\
\hline
\end{tabular}


The most common exercises used to develop the strength abilities of football players

\begin{tabular}{|c|c|}
\hline Name of the exercise & Description \\
\hline Squat & $\begin{array}{l}\text { S.P. - stand legs apart. The squat was performed to an angle of } 90^{\circ} \text { and fixed } \\
\text { for } 3 \text { seconds, then a quick rise to the starting position. }\end{array}$ \\
\hline Bench press & $\begin{array}{l}\text { S.P. - lying on the bench, holding the barbell bar. The head is pressed against } \\
\text { the bench, the shoulder blades are brought together, the feet rest on the floor. } \\
\text { During the exercise, the barbell moves in a vertical plane. }\end{array}$ \\
\hline Block traction on the simulator & $\begin{array}{l}\text { S.P. - Stand legs apart, legs slightly bent at the knee joints, shoulder blades } \\
\text { brought together, pull from top to bottom, up to waist level. }\end{array}$ \\
\hline Ascents of the platform & $\begin{array}{l}\text { Platfom height of } 40-50 \mathrm{~cm} \text {, stepping on the platform to perform an angle of } \\
90^{\circ} \text {. The same goes for the barbell neck. }\end{array}$ \\
\hline Lifting barbells & $\begin{array}{l}\text { S.P. - stand legs apart, legs slightly bent at the knee joints, shoulder blades } \\
\text { brought together, barbells in the hands. Perform arm flexion. }\end{array}$ \\
\hline $\begin{array}{l}\text { Lifting the torso with emphasis on } \\
\text { one leg }\end{array}$ & $\begin{array}{l}\text { S.P. - lying down, the heel of one foot rests on the floor. Lift the torso, leaning } \\
\text { on the floor with the shoulder blades and one leg. }\end{array}$ \\
\hline $\begin{array}{l}\text { Lifting barbells from a sitting } \\
\text { position }\end{array}$ & $\begin{array}{l}\text { S.P. - sitting, hands with barbells to the sides, forearms up. Lifting your hands } \\
\text { up, touch the barbells, then return to the starting position. }\end{array}$ \\
\hline Jumping & S.P.- half-squat. Jumping on the pedestal followed by a quick jump up. \\
\hline Flexion and extension of the torso & $\begin{array}{l}\text { S.P. - lying on your back. Simultaneous lifting of the torso and bent legs so } \\
\text { that the chin is close to the knees. The body after performing the exercise is } \\
\text { completely lowered to the floor. }\end{array}$ \\
\hline Hip turns with medball & $\begin{array}{l}\text { S.P. - lying down, hold the medball between your knees. Make a movement } \\
\text { with your hips to the right and left, do not touch the floor with your feet. }\end{array}$ \\
\hline
\end{tabular}

of times.

2. Exercises with external weights, performed for a time.

3 . Exercises performed in the statodynamic mode.

4. Jumping exercises performed on the number of times.

In our opinion, the most popular way to develop maximum strength is the method of unsaturated effort (within $80-85 \%$ of the individual maximum), the number of repetitions in the exercises varies from 8 to 16 repetitions. This method allows for a longer impact on the muscle fibers through a relatively large number of motor actions, which allows you to simultaneously increase the strength and mass of the muscle fibers [20]. The exercises used in the experiment are presented in Table 2.

Note: weights are selected individually

The strength training for the experimental group consisted of two parts:

(C) Lashkevich S., Vrublevskiy E., Kozhedub M., Medvedev P., 2021
1. Training on the method of unsaturated repeated efforts, which was of a complex nature.

2. Tonic training based on the circular method with a weight gain ( $40 \%$ of the maximum weight), but with an increase in the number of repetitions. The strength training of football players was not limited to the above set of exercises, it was changed every training cycle (the most frequently used exercises are described).

Table 3 shows that statistically significant differences between the experimental and control groups were found in all the analyzed values of power characteristics at the end of the pedexperiment $(\mathrm{p}<0.05)$.

Discussion. The value of the force displayed in 0.1 seconds can be attributed to the factor of determining the speed abilities of football players. With an increase of $26.8 \mathrm{~kg}$ for the right leg and 19.5 $\mathrm{kg}$ for the left leg, the players were able to improve their result in the 30 -meter run by $4.02 \%$. Before the experiment the players ran this segment, on average, for 4.23 seconds, whereas after that, the time was 4.06 seconds.

The analysis of individual indicators of football players revealed that the defensive line players have the largest increase in the maximum isometric strength, and the offensive players have a lower increase in the manifestation of this indicator. At the same time, attack players have the highest rates in the manifestation of force for $0.1 \mathrm{~s}$ and "explosive" muscle contraction (force gradient).

Conclusions. The individualization of special strength training of qualified football players, which was carried out by selecting the optimal weight for each player, as well as a set of speed and strength exercises, had a positive effect on the indicators of the dynamic characteristics of the players. The varia- 
Dynamometric indicators of qualified football players after the experiment

\begin{tabular}{|l|c|c|c|c|}
\hline \multirow{2}{*}{$\begin{array}{c}\text { Dynamometric } \\
\text { Indicators }\end{array}$} & $\begin{array}{c}\text { Control } \\
\mathrm{n}=10\end{array}$ & $\begin{array}{c}\text { Experimental } \\
\mathrm{n}=10\end{array}$ & Validity of differences \\
\cline { 2 - 5 } & \multicolumn{7}{|c|}{ Right leg } & $\mathrm{p}$ \\
\hline \multicolumn{7}{|c|}{ Left leg } \\
\hline Maximum isometric force, $\mathrm{kg}$ & $236,1 \pm 4,6$ & $263,2 \pm 9,4$ & 2,57 & $<0,05$ \\
\hline Force gradient, $\mathrm{kg} / \mathrm{s}$ & $210,5 \pm 7,2$ & $234,9 \pm 6,8$ & 2,46 & $<0,05$ \\
\hline Force exerted in 0,1 s, $\mathrm{kg}$ & $124,3 \pm 6,8$ & $147,3 \pm 6,2$ & 2,50 & $<0,05$ \\
\hline \multicolumn{7}{|c|}{} \\
\hline Maximum isometric force, $\mathrm{kg}$ & $223,3 \pm 7,4$ & $246,3 \pm 4,6$ & 2,64 & $<0,05$ \\
\hline Force gradient, $\mathrm{kg} / \mathrm{s}$ & $193,1 \pm 6,0$ & $212,0 \pm 6,0$ & 2,23 & $<0,05$ \\
\hline Force exerted in 0,1 s, $\mathrm{kg}$ & $118,4 \pm 7,4$ & $137,1 \pm 6,8$ & 2,56 & $<0,05$ \\
\hline
\end{tabular}

tion in different modes (isometric, dynamic, and statodynamic) of individually directed training actions allowed for a more complete effect on the muscle fibers of the players, which contributed to the qualitative manifestation of the players' conditions in training and competitive activities.

The implementation of motor actions shown by football players in the game is not directly related to the indicators of the maximum isometric strength shown by players when extending the leg in the knee and hip joints. At the same time, athletes with higher performance in this parameter will be able to jump higher to fight for riding balls. The same players who can show their maximum power capabilities in a short time, have higher indicators in the manifestation of high-speed effects, which is one of the most im- portant characteristics in the game activity of a football player.

Thus, the rational organization of special strength training of football players and the development of objective control over the level and dynamics of their strength characteristics should be considered as a potential reserve that contributes to the qualitative improvement of the training process of football players of various roles.

\section{Література}

1. Анпилогов И.Е., Врублевский Е.П. Методика специальной скоростно-силовой подготовки юношей-спринтеров на основе применения средств локально-избирательного воздействия. Теория и практика физической культуры. 2011. № 4. С. 72.

2. Врублевский Е.П., Козьмин Р.К. В помощь тренеру. Легкая атлетика. 1983. № 12. С. 13.

3. Врублевский Е.П., Лашкевич С.В., Шеренда С.В. Объем тренировочных нагрузок квалифицированных футболистов в подготовительном периоде // Игровые виды спорта: актуальные вопросы теории и практики: сб. науч. статей: Воронеж: ООО «РИТМ», 2019. С. 36-39.

4. Губа В.П., Лексаков В.Н. Теория и методика футбола: учебник. - М.: Физическая культура, 2013. $576 \mathrm{c}$.

5. Губа В.П., Шамардин А.А. Комплексный контроль интегральной функциональной подготовленности футболистов: монография. - М.: Советский спорт, 2015. 284 с.

\section{References}

1. Anpilogov I.Ye., Vrublevskiy Ye.P. (2011). Metodika spetsial'noy skorostno-silovoy podgotovki yunoshey-sprinterov na osnove primeneniya sredstv lokal'no-izbiratel'nogo vozdeystviy [The method of special speed and strength training of young sprinters based on the use of means of local selective influence]. Theory and practice of physical culture. №4.72 [in Russian].

2. Vrublevskiy, Ye.P., R.K. Koz'min (1983). V pomoshch' treneru [To help the coach]. Athletics. № 12:13 [in Russian].

3. Vrublevskiy Ye.P., Lashkevich S.V., Sherenda S.V. (2019). Ob"yem trenirovochnykh nagruzok kvalifitsirovannykh futbolistov v podgotovitel'nom protsesse [The volume of training loads of qualified football players in the preparatory process]. Igrovyye vidy sporta: aktual'nyye voprosy teorii i praktiki: sb. nauch. statey: Voronezh: OOO «RITM», 36-39 [in Russian].

4. Guba V.P., Leksakov V.N. (2013). Teoriya i metodika futbola [Theory and methodology of football]: textbook. - M.: Physical culture [in Russian]. 
6. Губа В.П., Скрипко А.И., Стула А.Л. Тестирование и контроль подготовленности футболистов. - М.: Спорт, 2016. 167 с.

7. Гусинец Е.В., Костюченко В.Ф., Врублевский Е.П. Управление тренировочным процессом квалифицированных бегунов на короткие дистанции на основе миометрических показателей мышечной системы. Ученые записки университета имени П.Ф. Лесгафта. 2012. № 5 (87). С. 30-34.

8. Костюкевич В.М., Врублевский Е.П. Модели тактики игры в футбол: монография. - М.: Спорт, 2020. 168 с.

9. Костюкевич В.М., Врублевський Є.П., Вознюк Т.В. [та ін.]; Теоретико-методичні основи контролю у фізичному вихованні та спорті: монографія / за заг. ред. В.М.Костюкевича. - Вінниця: ТОВ «Планер», 2017. 191 с.

10. Костюченко В.Ф., Врублевский Е.П., Боровая В.А. Классификация специальных упражнений, применяемых в тренировке метателей (на примере метания копья). Ученые записки университета им. П. Ф. Лесгафта. 2014. 5 (111). С.7077.

11. Костюченко В.Ф., Врублевский Е.П., Кожедуб М.С. Влияние биоритмики организма квалифицированных спортсменок на динамику их двигательных способностей. Ученые записки университета имени П.Ф. Лесгафта. 2018. № 4 (158). С. 159-164.

12. Лашкевич С.В., Вырский М.М., Врублевский Е.П., Митусова Е.Д. Контроль за восстановлением работоспособности футболистов в процессе тренировочных занятий. Физическая культура: воспитание, образование, тренировка. 2020. № 6. С. 17-19.

13. Мирзоев О.М., Врублевский Е.П. Теоретические и методические основы индивидуализации тренировочного процесса легкоатлетов: метод. пособие. М.: РГУФК, 2006. 100 с.

14. Литвинов Р.В. Оценка мастерства ударных действий футболистов. Электронный научно-методический журнал Омского ГАУ. 2018. №. 1 (12). C. 36-37.

15. Майер Р. Силовые тренировки в футболе. Перевод с анг. языка. - М.: Спорт, 2016. С. 128 с.

16. Нарскин А.Г., Мельников С.В., Врублевский Е.П., Костюченко В.Ф., Орехов Е.Ф. Эффективность использования жизненной емкости легких у пловцов различной специализации. Ученые записки университета им. П.Ф. Лесгафта. 2016. №2(132). С.135-139.

17. Привалов А.В. Повышение технической подготовленности футболистов на основе коррекции силовых возможностей отдельных мышечных групп. Ученые записки университета имени
5. Guba V.P., Shamardin A.A. (2015). Kompleksnyy kontrol' integral'noy funktsional'noy podgotovlennosti futbolistov: monografiya [Comprehensive control of the integral functional fitness of football players]. - Moscow: Sovetskiy sport [in Russian].

6. Guba V.P., Skripko A.I., Stula A.L. (2016). Testirovaniye i kontrol' podgotovlennosti futbolistov [Testing and control of football players ' fitness]. Moscow: Sport. [in Russian].

7. Gusinets Ye.V., Kostyuchenko V.F., Vrublevskiy Ye.P. (2012) Upravleniye trenirovochnym protsessom kvalifitsirovannykh begunov na korotkiye distantsii na osnove miometricheskikh pokazateley myshechnoy sistemy [Management of the training process of qualified short-distance runners based on myometric indicators of the muscular system]. Uchenyye zapiski universiteta imeni P.F. Lesgafta, № 5 (87), 30-34 [in Russian].

8. Kostyukevich V.M., Vrublevskiy Ye.P. (2020). Modeli taktiki igry v futbol: monografiya [Models of football game tactics]. Moscow: Sport [in Russian].

9. Kostyukevich V.M., Vrublevskiy E.P., Voznyuk T.V. (2017). Teoretyko-metodychni osnovy kontrolyu u fizychnomu vykhovanni ta sporti: monohrafiya [Theoretical and methodological foundations of control in physical education and sports]. Vinnytsya: TOV «Planer» [in Ukrainian].

11. Kostyuchenko V.F., Vrublevskiy Ye.P., Borovaya V.A. (2014). Klassifikatsiya spetsial'nykh uprazhneniy, primenyayemykh $\mathrm{v}$ trenirovke metateley (na primere metaniya kop'ya) [Classification of special exercises used in the training of throwers (for example, javelin throwing)]. Uchenyye zapiski universiteta im. P.F. Lesgafta, №5 (111). 70-77 [in Russian].

11. Kostyuchenko V.F., Vrublevskiy Ye.P., Kozhedub M.S. (2018). Vliyaniye bioritmiki organizma kvalifitsirovannykh sportsmenok na dinamiku ikh dvigatel'nykh sposobnostey [Influence of biorhythmics of the body of qualified athletes on the dynamics of their motor abilities]. Uchenyye zapiski universiteta imeni P.F. Lesgafta, № 4 (158). 159164 [in Russian].

12. Lashkevich S.V., Vyrskiy M.M., Vrublevskiy Ye.P., Mitusova Ye.D. (2020) Kontrol' za vosstanovleniyem rabotosposobnosti futbolistov v protsesse trenirovochnykh zanyatiy [Control over the restoration of the players ' performance during training sessions]. Fizicheskaya kul'tura: vospitaniye, obrazovaniye, trenirovka. № 6. 17-19 [in Russian].

13. Mirzoyev O.M., Vrublevskiy Ye.P. (2006). Teoreticheskiye i metodicheskiye osnovy individualizatsii trenirovochnogo protsessa legkoatletov [Theoretical and methodological foundations of individualization of the training process of athletes]:

(C) Lashkevich S., Vrublevskiy E., 
П.Ф. Лесгафта. 2017. № 2 (144). С. 196-201.

18. Севдалев С.В., Врублевский Е.П., Кожедуб М.С. Особенности предсоревновательной подготовки квалифицированных спортсменок, специализирующихся в современном пятиборье. Физическая культура и спорт в современном мире: к 70-летию факультета физической культуры: сб. науч. статей. Гомель: ГГУ им. Ф. Скорины. 2019. C. 378-381.

19. Севдалев С.В., Кожедуб М.С., Врублевский Е.П., Митусова Е.Д. Индивидуализация тренировочного процесса легкоатлеток, специализирующихся в беге на разные дистанции, на основе учета биоритмики их организма. Теория и практика физической культуры. 2020. №5. С.83-85.

20. Селуянов В.Н, Васильев А.В. Диас С. Инновационная технология физической подготовки футболистов на основе развития локальной мышечной выносливости. Физическая культура: воспитание, образование, тренировка. 2013. №. 4. C. 47-48.

21. Федоскина Е.М., Врублевский Е.П., Мирзоев О.М. Ценностные ориентации легкоатлетов-спринтеров и барьеристов высокой квалификации. Теория и практика физической культуры. 2009. № 10. С. 16.

22. Яковлев А.Н. Врублевский Е.П., Стадник В.И., Кравченин А.А., Яковлева М.А., Глушенко Н.А. Восприятие будущего в процессе занятий физкультурно-спортивной деятельностью: проблемы и перспективы. Теория и практика физической культуры. 2020. № 1. С. 98-100.

23. Kostiukevych V., Skrypko A., Vrublevskiy E., Lamcha Ł. Tactics and movement control in football: monografia. Kalisz: Kaliskie Towarzystwo Przyjaciol Nauk, 2020. 160 p.

24. Vrublevskiy E.P., Khorshid A.Kh., Albarkaii D.A. Focused strength and speed-strength trainings of sprinters. Teoriya i Praktika Fizicheskoy Kultury. 2019. № 4. P. 35.

25. Vrublevskiy E., Kozhedub, M. The level of specyfic motor properties in the individual phases of the menstrual cycle among young sportswomen practicing sprints. Rocznik Lubuski. 2018. T. 44. № 2A. pp. 105-115.

26. Vrublevskiy E.P., Sevdalev S.V., Lashkevich S.V., Gerkusov A.S. Modelling of the competitive activities of qualified female short-distance runners, taking into account their individual characteristics . Physical education of student. 2019. No. 6. pp. 320-326.

27. Vrublevskiy E., Skrypko A., Asienkiewicz R. Individualization of selection and training of female athletes in speed-power athletics from the perspective of gender identity. Physical education method. manual. Moscow: RSUFC [in Russian].

14. Litvinov R.V. (2018). Otsenka masterstva udarnykh deystviy futbolistov [Assessment of the skill of striking actions of football players]. Elektronnyy nauchno-metodicheskiy zhurnal Omskogo GAU, №. 1 (12). 36-37 [in Russian].

15. Mayyer R. (2016). Strength training in football. Translated from Ang. language. - M.: Sport [in Russian].

16. Narskin A.G., Mel'nikov S.V., Vrublevskiy Ye.P., Kostyuchenko V.F., Orekhov Ye.F. (2016). Effektivnost' ispol'zovaniya zhiznennoy yemkosti legkikh u plovtsov razlichnoy spetsializatsii [The effectiveness of the use of the vital force of the lungs in swimmers of various specializations]. Uchenyye zapiski universiteta im. P.F. Lesgafta, №2(132). 135-139 [in Russian].

17. Privalov A.V. (2017). Povysheniye tekhnicheskoy podgotovlennosti futbolistov na osnove korrektsii silovykh vozmozhnostey otdel'nykh myshechnykh grupp. Uchenyye zapiski universiteta imeni P.F. Lesgafta. № 2 (144). 196-201 [in Russian].

18. Sevdalev S.V., Vrublevskiy Ye.P., Kozhedub M.S. (2019). Osobennosti predsorevnovatel'noy podgotovki kvalifitsirovannykh sportsmenok, spetsializiruyushchikhsya $\mathrm{v}$ sovremennom pyatibor'ye [Features of pre-competition training of qualified athletes specializing in modern pentathlon]. Physical culture and sport in the modern world: to the 70th anniversary of the Faculty of Physical Culture: sat.nauch. articles.. - Gomel': GGU im. F. Skoriny, 378-381 [in Russian].

19. Sevdalev S.V., Kozhedub M.S., Vrublevskiy Ye.P., Mitusova Ye.D. (2020). Individualizatsiya trenirovochnogo protsessa legkoatletok, spetsializiruyushchikhsya $\mathrm{v}$ bege na raznyye distantsii, na osnove ucheta bioritmiki ikh organizma [Individualization of the training process of athletes specializing in running at different distances, based on the biorhythmics of their body]. Theory and practice of physical culture, №5. 83-85 [in Russian].

20. Seluyanov V.N, Vasil'yev A.V. Dias S. (2013). Innovatsionnaya tekhnologiya fizicheskoy podgotovki futbolistov na osnove razvitiya lokal'noy myshechnoy vynoslivosti [Innovative technology of physical training of football players based on the development of local muscle endurance]. Fizicheskaya kul'tura: vospitaniye, obrazovaniye, trenirovka, №4. 47-48 [in Russian].

21. Fedoskina Ye.M., Vrublevskiy Ye.P., Mirzoyev O.M. (2009). Tsennostnyye oriyentatsii legkoatletov-sprinterov i bar'yeristov vysokoy kvalifikatsii [Value orientations of track and field sprinters and hurdlers of high qualification]. Teoriya i praktika fizicheskoy kul'tury, № 10.16 [in Russian].

22. Yakovlev A.N. Vrublevsky E.P., Stadnik V.I., 
of students. 2020. T.24. №.4. C. 227-234.
Kravchenin A.A., Yakovleva M.A., Glushenko N.A. (2020). Vospriyatiye budushchego v protsesse zanyatiy fizkul'turno-sportivnoy deyatel'nost'yu: problemy i perspektivy [Perception of the future in the process of physical culture and sports activities: problems and prospects]. Theory and practice of physical culture. No. 1. 98-100 [in Russian].

23. Kostiukevych V., Skrypko A., Vrublevskiy E., Lamcha Ł. (2020) Tactics and movement control in football: monografia. Kalisz: Kaliskie Towarzystwo Przyjaciol Nauk, 2020. 160 p.

24. Vrublevskiy E.P., Khorshid A.Kh., Albarkaii D.A. (2019). Focused strength and speed-strength trainings of sprinters // Teoriya i Praktika Fizicheskoy Kultury. 4. 35 [in Russian].

25. Vrublevskiy E., Kozhedub M. (2018). The level of specyfic motor properties in the individual phases of the menstrual cycle among young sportswomen practicing sprints. Rocznik Lubuski, t. 44. № $2 \mathrm{~A}$. 105-115.

26. Vrublevskiy E.P., Sevdalev S.V., Lashkevich S.V., Gerkusov A.S. (2019) Modelling of the competitive activities of qualified female short-distance runners, taking into account their individual characteristics . Physical education of student, No. 6. 320-326.

27. Vrublevskiy E., Skrypko A., Asienkiewicz R. (2020). Individualization of selection and training of female athletes in speed-power athletics from the perspective of gender identity. Physical education of student, T.24. 4. 227-234.

\section{Лашкевич Сергей}

Учреждение образования «Гомельский государственный университет имени Франциска Скорины» г. Гомель, ул. Советская, 104, 246019, Республика Беларусь e-mail: lashkevichsergey@mail.ru

ORCID https://orcid.org/0000-0001-7029-9552

\section{Врублевский Евгений Павлович}

Учреждение образования «Гомельский государственный университет имени Франциска Скорины» г. Гомель, ул. Советская, 104, 246019, Республика Беларусь

Зеленогурский университет, Зелена-Гура, Польша

e-mail: vru-evg@yandex.ru

ORCID https://orcid.org/0000-0001-5053-7090

\section{Кожедуб Марина}

Учреждение образования «Гомельский государственный университет имени Франциска Скорины» г. Гомель, ул. Советская, 104, 246019, Республика Беларусь

e-mail: marina.888.k@yandex.ru, тел.+375 296377931

\section{Медведев Павел}

Учреждение образования «Гомельский государственный университет имени Франциска Скорины»

г. Гомель, ул. Советская, 104, 246019, Республика Беларусь

e-mail: Medvedev.91@bk.ru, тел.+375296781809

ORCID https://orcid.org/0000-0003-1114-6139 